\title{
Staða heimilislækninga á Íslandi í dag
}

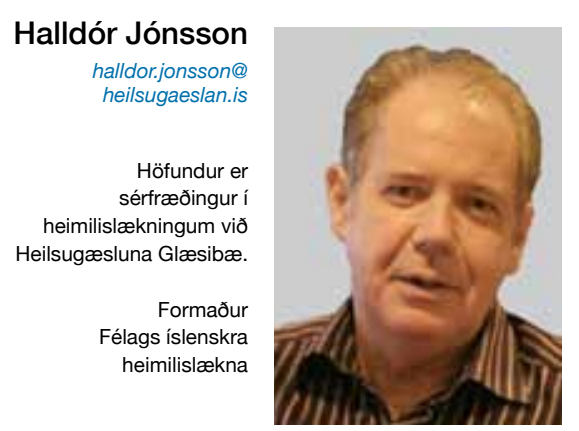

FYRIR NOKKRUM ÁRUM var ég spurður um hvað mér pætti mestu skipta fyrir heimilislækningar. Eftirfarandi punktar komu pá upp í hugann:

- Að heilsugæslan sé ríkisrekin, með eðlilega mönnun og búi ekki við fjársvelti. Hún starfi í tengslum við aðrar heilbrigðis- og félagslegar stofnanir.

- Lög og reglugerðir taki mið af pörfum heilsugæslunnar og styrki stöðu hennar sem miðpunkts heilbrigðispjónustu.

- Samhliða ríkisrekstri séu markvisst reynd önnur rekstrarform til pess að finna leið sem veiti sem besta pjónustu á allra hagkvæmasta hátt, án pess að gæði pjónustunnar séu minni en opinbera kerfið veitir.

- Engar breytingar séu gerðar á starfssviði heilsugæslu og störfum heimilislækna án pess að peirra álits sé leitað fyrst.

Eins og sjá má hér að ofan virðast stjórnvöld ekki hafa verið á sama máli. Undirmönnun og fjársvelti heilsugæslunnar er viðvarandi. Fátt hefur verið gert til að styrkja heilsugæsluna sem miðpunkt heilbrigðispjónustu. Verkefnum hefur verið fjölgað án aukins mannafla eða fjármagns. Önnur rekstrarform fást ekki reynd, samanber samninga Félags íslenskra heimilislækna (FÍH) og Sjúkratrygginga Íslands frá árinu 2008. Loks er verið að framkvæma breytingar á störfum heimilislækna án pess að peir eða fagfélag peirra fái að koma par að nema sem umsagnaraðili á lokastigum. Pví hefur verið haldið fram í ræðu og riti að heimilislæknar sinni ekki starfsskyldum sínum á dagvinnutíma. Par hafa ýmsir talnaspekingar borið komufjölda á dagvinnutíma hjá heimilislækni saman við komur á vaktpjónustu. Að degi til sækja einstaklingar með fjölpætt vandamál, gjörólíkt pví sem gerist á vaktinni. Atvinnurógi af pessu tagi verður að linna.

Heimilislæknismóttakan er kjarni heilsugæslunnar og sá hluti sem er viðkvæmastur fyrir undirmönnun. Greiður aðgangur að heimilislækni, pekking á sjúklingi og fjölskyldu hans, ásamt trausti og samfellu í meðferð, er pað mikilvægasta í pjónustu heilsugæslunnar og skiptir höfuðmáli. Slíkt verklag sparar mikla fjármuni.

Petta er grunnur að hugmyndafræði heimilislækninga sem FÍH hefur verið að berjast fyrir síðustu áratugi.

FÍH hefur um árabil unnið að, endurskoðað reglulega og gefið út staðla um starfsemi og starfsaðstöðu heimilislækna, síðast 2008. Staðallinn skiptist í fjóra ýtarlega pætti: um starfshætti, starf, húsnæði og búnað á heilsugæslustöð.

En hvernig er ástandið? Á síðustu árum hafa orðið miklar breytingar á umhverfi heimilislækninga. Má fyrst nefna fækkun sérmenntaðra heimilislækna á landsbyggðinni og erfiðleika við að manna stöður. Á uppgangsárunum fjölgaði íbúum á höfuðborgarsvæðinu án pess að til kæmi fjölgun heimilislækna. Skjólstæðingar voru skráðir á heilsugæslustöðvar prátt fyrir skort á heimilislæknum og álag pví aukið á stöðvarnar. Eftir hrun hefur heimilislæknum fækkað, peir hafa horfið til annarra starfa hérlendis eða erlendis. Peir sem eftir eru vinna við sífellt meira álag.

Heimilislækningar hafa lengi verið sagður hornsteinn heilbrigðiskerfisins. Par eigi fólk að hefja samskipti sín og par eigi verulegur hluti eftirlits að vera. Prátt fyrir petta er lítið sem ekkert gert til að gera starfið eftirsóknarvert til að örva nýliðun og enn sem fyrr er talað um að flyja aukin verkefni til heimilislækna.

Heimilislæknar hafa á undanförnum árum lagt mikla vinnu í að laða til sín læknanema í sérnám. Námið tekur fjögur til fimm ár og í pví eru nú á annan tug ungra lækna. Pá munu nokkrir stunda sérnám erlendis. Boðuð hefur verið fjölgun á námsstöðum í heimilislækningum en hún hefur enn ekki litið dagsins ljós. Sérmenntuðum heimilislæknum mun fækka um helming á næstu 8-10 árum vegna aldurssamsetningar hópsins. Ástand sem hefur verið alvarlegt um nokkurt skeið verður óviðráðanlegt innan fárra ára nema brugðist verði við á markvissan hátt.

Hvað er til ráða? Strax verður að hefja vinnu við að bæta starfsgrundvöll heimilislækninganna, meðal annars með pví að draga til baka skerðingu á ráðningarkjörum.

Fjölga mætti læknariturum frekar en að læknar skrifi sjúkraskrár og vottorð sjálfir, sumir hverjir með tveimur fingrum. Kanna verður meðal heimilislækna pörf á annarri aðstoð. Fjölga parf námsstöðum strax en fyrstu læknar peirrar aukningar skila sér inn í kerfið eftir um fimm ár. Pá er eðlilegt að FÍH komi að öllum nefndastörfum er varða heimilislækningar.

Félag íslenskra heimilislækna hefur um árabil varað við pessari próun. Félagið hefur ítrekað boðið stjórnvöldum samvinnu um lausn yfirstandandi vanda en pví miður hefur peim boðum ekki verið sinnt. Ljóst er af stöðu mála í dag að pessi afstaða er að leiða heilbrigðiskerfið inn í blindgötu og hvetjum við ráðuneytið til að kalla félagið til samstarfs svo leita megi lausna á aðsteðjandi vanda. Ætli menn að halda áfram pjónustu í peim anda sem kennd hefur verið við norræna heilbrigðispjónustu og velferðarsamfélag er pað eina lausnin. Stefni hugur stjórnvalda annað er eðlilegt að slíkt sé tilkynnt peim sem nú vinna við heimilislækningar svo peir geti gert upp við sig hvernig og hvar peir hyggist starfa í framtíðinni.

General practice in Iceland, the present situation

Halldór Jónsson MD, MMSc- International Health, Specialist in Family Medicine at Glæsibær Health Centre, Reykjavik, Iceland. Chairman of the Icelandic College of Family physicians 